Article

\title{
Experimental Air-Tightness Analysis in Mediterranean Buildings after Windows Retrofit
}

\author{
Francesca Romana d'Ambrosio Alfano ${ }^{1, *}$, Marco Dell'Isola ${ }^{2}$, Giorgio Ficco ${ }^{2}$, Boris Igor Palella ${ }^{3}$ \\ and Giuseppe Riccio ${ }^{3}$ \\ 1 Dipartimento di Ingegneria Industriale (DIIn), Università degli Studi di Salerno, Via Giovanni Paolo II 132, \\ 84084 Fisciano, Italy \\ 2 Dipartimento di Ingegneria Civile e Meccanica (DICEM), Università di Cassino e del Lazio Meridionale, \\ Via G. Di Blasio 43, 03043 Cassino, Italy; dellisola@unicas.it (M.D.); ficco@unicas.it (G.F.) \\ 3 Dipartimento di Ingegneria Industriale (DII), Università degli Studi di Napoli Federico II, \\ Piazzale Vincenzo Tecchio 80, 80125 Naples, Italy; palella@unina.it (B.I.P.); riccio@unina.it (G.R.) \\ * Correspondence: fdambrosio@unisa.it; Tel.: +39-089-964-107
}

Academic Editors: Francesco Asdrubali and Pietro Buzzini

Received: 8 June 2016; Accepted: 22 September 2016; Published: 30 September 2016

\begin{abstract}
Energy saving and Indoor Air Quality (IAQ) in buildings are strongly affected by air leakages. Several studies reveal that the energy loss owing to leaky windows can account for up to $40 \%$ of the total building energy demand. Furthermore, at the design stage, the possible infiltration of outdoor air through windows is not taken into account when determining the nominal outdoor airflow rate of the ventilation system. This practice may result in an oversizing of the ventilation system and consequent energy waste. Thus, the air-tightness class of a wall assembly should be assessed for each window component considering the type of material, the presence of the seal, the type of closure, the sealing and the maintenance condition. In this paper, the authors present the experimental results of air-tightness measurements carried out using the fan pressurization method in three residential buildings located in the Mediterranean region before and after a window retrofit. Two different window retrofits were investigated: the application of rubber seals on window frames and the substitution of existing windows with new certified high performance windows. The effectiveness of such retrofits was estimated also in terms of energy saving. Test results demonstrated a high variability of the building air tightness after window retrofits, despite the fact that air tight-certified windows were used.
\end{abstract}

Keywords: air-tightness; building envelope; Indoor Air Quality; IAQ; energy saving; ventilation; building retrofit; fan pressurization test; window

\section{Introduction}

The retrofit of existing residential stock provides significant opportunities and challenges in terms of new systems and components and in terms of the related energy saving [1,2].

Operating on opaque and transparent walls is an effective strategy to reduce heat losses through the building envelope. Unfortunately, the retrofit of opaque elements is often difficult, especially when buildings exhibit historical constraints (e.g., in Mediterranean countries) or aesthetic peculiarities that avoid invasive solutions such as external insulation. On the other hand, operating on windows is undoubtedly easier and this can be applied also to historical buildings [3] by reproducing the original window frame with high performance materials.

In recent decades there has been an increased focus on the reduction of the thermal transmittance of building components [4,5] and related measurement techniques applicable in the field [6]. On the other hand, the requirements for ensuring buildings' air-tightness are too often disregarded [7]. 
At the EU policy level, improving building air-tightness is a crucial issue of Energy Performance of Buildings Directive (EPBD) recast since for most European climates and countries, good air-tightness performances are necessary for nearly-zero-energy buildings [8]. In fact, energy savings of $10 \mathrm{kWh}$ per $\mathrm{m}^{2}$ of floor area per year for the heating needs in a cold region (e.g., 2500 degree day) should be expected [9]. As a consequence, several EU countries (e.g., Czech Republic, Denmark, France, Germany, Ireland, The Netherlands, Norway, Portugal, the United Kingdom) require or recommend minimum air-tightness levels (with or without mandatory testing). This is the reason why the number of tests performed is then rapidly increasing [9].

Although air-tightness tests are often included in national energy performance regulations (e.g., in Belgium, Denmark, France, Germany, Sweden and the United Kingdom), in practice there are major differences in the way this issue is taken into account. The development of standard test procedures represents an opportunity for improving the reliability of the building air-tightness tests. Schemes are based on EN 13829 [10] and ISO 9972 [11]. The default value for building air-tightness differs from country to country, which is not surprising given the differences in building traditions and construction types. Several countries use the reference value $\Delta p=50 \mathrm{~Pa}$ for the indoor-outdoor static pressure difference to be used during tests (e.g., Denmark, Sweden, Belgium, and the United Kingdom) [12,13].

As observed by American Society of Heating, Refrigerating and Air-Conditioning Engineers (ASHRAE) [14], many factors are responsible for the air leakages through the building envelope. Consequently, the preliminary building assessment is not always a simple task owing to the characteristics (e.g., geometry, row, court or tower), materials (e.g., concrete, bricks or wood, traditional or precast construction), components (e.g., windows and doors, chimney, pipes and ducts for conditioning or electrical systems), age and/or the maintenance state of the building.

Several studies on building air-tightness and related measurement techniques are nowadays available in international literature, but most of them have been carried out in cold climates such as in Northern Europe, Canada and the USA [15-18]. In the last years, the interest in air-tightness in building envelopes has increased, mainly due to the rising concern toward energy saving, even in southern European countries with a Mediterranean climate [19,20].

Windows and doors are one of the main elements responsible for air leakages. Thus, window retrofits can be very effective to enhance the overall energy performance and to reduce air leakages when it is impossible to operate on opaque walls. Unfortunately, air-tight windows nullify the airing [21] and worsen the Indoor Environmental Quality (IEQ). It is well known that assuring high energy saving has to be consistent with acceptable IEQ levels in terms of IAQ and thermal comfort [22]. Regarding the IAQ, the air change rate is generally favored by air leakages, even they are unfiltered and uncontrolled [23]. On the contrary, as regards the thermal comfort, air leakages can generate a local discomfort due to draught and local temperature differences. As a result, the energy demand to obtain acceptable IEQ levels increases. This is even more important in Mediterranean countries where climatic changes result in cooler winters and hotter summers [24].

Furthermore, at the mechanical ventilation system design stage, air infiltrations are generally overlooked when the nominal air change rate of the system is calculated. Therefore, the wrong assessment of air infiltrations can lead to oversizing the ventilation system with unavoidable energy waste. Not by chance, ASHRAE Standard 62.2 [25] requires the reduction of mechanical ventilation if it can be shown that air infiltrations are above a certain level.

The evaluation of energy waste owing to air infiltrations appears even more difficult. In fact, in winter, air leakages always result in heat losses, especially in the absence of heat recovery units. An adequate mechanical ventilation system is obviously the most appropriate solution in new buildings in which air leakages could be minor if compared to air intakes. On the other hand, in existing buildings it is not possible to neglect air leakages; thus, during retrofit interventions it could be very useful to accurately investigate them in order to reduce or eliminate their main causes. Anyway, an incorrect installation can nullify the energetic benefits. 
In this paper the experimental results of air-tightness measurements carried out on three residential buildings in which different window retrofits were adopted are presented and discussed. Furthermore, the effectiveness of window retrofits has been investigated in terms of the reduction of air-tightness and in terms of the energy demand of the building.

\section{Materials and Methods}

The authors carried out a Blower Door Test (BDT) measurement campaign before and after different window retrofits on three buildings. Two window retrofits techniques were investigated: (A) the application of a new rubber seal on the window frames; (B) the substitution of the original windows with new certified high performance windows. In particular, for building 1 a simple not invasive windows retrofit was first applied: the existing wooden window frames were equipped with new rubber seals. Such a technique is very cheap and it is quite spread in Mediterranean area, especially in public housing dwellings. On the other hand, the substitution of windows with new certified high performance windows is always requested when better performance are needed and financial incentives (or tax breaks) can be obtained. In this paper, new PVC and aluminum thermal break windows characterized by high air-tightness performances (class 3 and 4 according to EN Standard 12207 [26]) have been investigated. In Table 1, the main characteristics of the buildings and investigated windows retrofits are summarized.

Table 1. Main characteristics of investigated window retrofits.

\begin{tabular}{|c|c|c|c|c|c|c|c|c|c|c|c|c|c|}
\hline \multicolumn{9}{|c|}{ Buildings } & \multicolumn{3}{|c|}{ Windows Retrofits } & \multicolumn{2}{|c|}{ Climate } \\
\hline Ref. & Year & $\begin{array}{l}\text { Vol. } \\
{\left[\mathrm{m}^{3}\right]}\end{array}$ & $\begin{array}{l}\text { Env. } \\
\text { Area } \\
{\left[\mathrm{m}^{2}\right]}\end{array}$ & $\begin{array}{l}\text { Net Floor } \\
\text { Area }\left[\mathrm{m}^{2}\right]\end{array}$ & $\begin{array}{c}\text { Net av. } \\
\text { Ceiling } \\
\text { Height [m] }\end{array}$ & $\begin{array}{l}\text { Height } \\
{[\mathrm{m}]}\end{array}$ & $\begin{array}{l}\text { Perimeter } \\
{[\mathrm{m}]}\end{array}$ & $\begin{array}{c}\text { Surface } \\
\text { Area } \\
{\left[\mathrm{m}^{2}\right]}\end{array}$ & $\begin{array}{l}\text { Before } \\
\text { Retrofit }\end{array}$ & $\begin{array}{l}\text { After } \\
\text { Retrofit }\end{array}$ & $\begin{array}{c}\text { Air } \\
\text { Tightness } \\
\text { Class [26] }\end{array}$ & $\begin{array}{l}\text { Zone } \\
\text { [27] }\end{array}$ & $\begin{array}{l}\text { DD } \\
{\left[{ }^{\circ} \mathrm{C}\right]}\end{array}$ \\
\hline n.1 & 1978 & 178.2 & 226.3 & 59.4 & 3.0 & 12.0 & 31.6 & 8.4 & W & $\mathrm{P}$ & 4 & & 1164 \\
\hline n.2 & 1951 & 436.0 & 417.5 & 121.1 & 3.6 & 17.4 & 31.7 & 18.7 & $\mathrm{~W}$ & A & 3 & $\mathrm{C}$ & 1164 \\
\hline n.3 & 1910 & 138.0 & 136.6 & 49.9 & 2.8 & 14.0 & 13.4 & 3.9 & I & A & 4 & & 1383 \\
\hline
\end{tabular}

Air leakages through the building envelope have been measured by means of the BDT method [10,11], based on the mechanical pressurization/depressurization of the entire building or of a part of it. In this way, the airflow rate through the building envelope $q_{e n v}$ is measured as a function of the indoor-outdoor static pressure difference $\Delta p$ according to the following equation:

$$
q_{e n v}=C_{e n v}(\Delta p)^{n}
$$

where $C_{e n v}$ and $n$ are the flow coefficient and the air pressure exponent (estimated by means of a simple linear regression), respectively.

The flow coefficient $C_{\text {env }}$ depends on the size of the building openings. Air pressure exponent $n$ varies in the range 0.5 to 1 for fully developed turbulent and laminar flows, respectively. Usually, a reference value $n=0.65$ is adopted. Such values are very important for effective diagnoses because they provide an accurate estimation of air leakages [28].

To calculate the main air-tightness parameters $\left(q_{50}, n_{50}, q_{a 50}\right.$ and $\left.w_{50}\right)$, the following equations should be used in which $q_{50}$ is calculated from (1) using $\Delta p=50 \mathrm{~Pa}$ and evaluating $C_{e n v}$ and $n$ at the standard values for air temperature $\left(20^{\circ} \mathrm{C}\right)$ and barometric pressure $(101,325 \mathrm{~Pa})[12,29]$ :

$$
\begin{aligned}
& n_{50}=\frac{q_{50}}{V} \\
& q_{a 50}=\frac{q_{50}}{A_{E}} \\
& w_{50}=\frac{q_{50}}{A_{F}}
\end{aligned}
$$


Other authors [30] refer to different values of $\Delta p$ (e.g., 1, 4, 10, 25, 50 and $75 \mathrm{~Pa}$ ). It is important to underline that the air change rate $\left(n_{50}\right)$ is different from the natural airflow rate (also called "effective flow rate") through the building envelope ( $\left.n_{\text {nat }}\right)$ given by the following equation [31]:

$$
n_{\text {nat }}=\frac{n_{50}}{N}
$$

To improve the sensitivity and repeatability of the test method for a wide variety of buildings and to reduce the influence of the weather, $n_{50}$ is normally evaluated under pressure difference values higher than natural ones (e.g., $50 \mathrm{~Pa}$ ). The value adopted for $N$ in Equation (5) ranges 10 to 30 [32], depending on the type and the age of the building, windows and the other openings, the ventilation systems, etc. Such a high variability does not affect the reliability of the method because BDT has to be considered a diagnostic method aimed to:

- estimate the air permeability of the entire building, or of a part of it, to declare the compliance with a design air-tightness specification;

- locate the air leakages sources and investigate their main causes;

- estimate the air leakages reduction after the retrofit (e.g., substitution of windows or doors).

On the technical hand, the air changes per hour $(\mathrm{ACH})$ is also used. $\mathrm{ACH}$ is defined as the ratio of inlet volumetric airflow rate and internal volume, in $\mathrm{h}^{-1}$, under operative conditions without considering the complex thermal and fluid dynamic interaction between the building envelope, the HVAC system and the outdoor weather. ACH takes into account both the air leakages and the inlet air intakes within the plant, depending on the type of mechanical ventilation system. $\mathrm{ACH}$ and $n_{\text {nat }}$ are equal if the ventilation system is not present or not in use.

ISO 9972 Standard [12] presents three different BDT methods: (i) method A, test of a building in use (i.e., during the cooling or heating season); (ii) method B, test of the building envelope (i.e., in which any intentional opening is closed or sealed); (iii) method C, test of the building in use (i.e., automatically regulated, externally air transfer devices sealed, other openings handled in the same way as for method A). In this paper method B has been used. All the tests have been performed under the following main conditions: (i) wind speed below $3 \mathrm{~m} \mathrm{~s}^{-1}$; (ii) product of building height by indoor-outdoor air temperature difference lower than $500 \mathrm{~m} \mathrm{~K}$; (iii) total volume of the building below $4000 \mathrm{~m}^{3}$.

The experimental measurement apparatus used in the present BDT campaign consisted in:

- a calibrated airproof fan fitted to the door by means of an extensible frame allowing the measurement of pressure differences (positive and negative);

- a flow rate regulation system able to set the value of indoor-outdoor pressure difference by varying the speed of the fan;

- two primary devices for the flow rate measurement (e.g., a calibrated orifice plate on the plate and a Pitot tube for low and high flow rate, respectively, with an expanded uncertainty of about $5 \%$ at approximately $95 \%$ probability);

- a digital micro-manometer, calibrated according to ASTM Standard E1258 [33] with an expanded uncertainty of about $1 \mathrm{~Pa}$ at approximately $95 \%$ probability, to measure the pressure difference both indoor/outdoor and up/downstream to the primary element;

- a thermo hygrometer for air temperature and relative humidity measurements;

- an infrared camera, a hot wire anemometer and a Pitot tube to locate the main critical air infiltrations in the building under test.

All measurement devices have been calibrated at LAMI, the Industrial Measurements Laboratory of the University of Cassino, calibration laboratory LAT No 105 accredited by the Italian National Body Accredia. 


\section{Results and Discussion}

In Tables 2 and 3, the experimental results are reported in terms of air leakages and related energy demand for ventilation, respectively. For the energy analysis, the air change rate $\left(n_{50}\right)$ reference value of $0.3 \mathrm{~h}^{-1}$ has been used as prescribed by law for residential buildings in Italy.

Table 2. Experimental results for the investigated window retrofits.

\begin{tabular}{|c|c|c|c|c|c|c|c|}
\hline $\begin{array}{c}\text { Building } \\
\text { under Test }\end{array}$ & $\begin{array}{c}\text { Windows } \\
\text { Retrofit }\end{array}$ & $\begin{array}{c}\text { Leakage Rate } \\
{\left[\mathrm{m}^{3} \cdot \mathrm{h}^{-1}\right]}\end{array}$ & $n_{50}\left[\mathrm{~h}^{-1}\right]$ & $\begin{array}{c}n_{n a t}=n_{50} / 20 \\
{\left[\mathrm{~h}^{-1}\right]}\end{array}$ & $\begin{array}{c}w_{50} \\
{\left[\mathrm{~m} \cdot \mathrm{h}^{-1}\right]}\end{array}$ & $\begin{array}{c}q_{a 50} \\
{\left[\mathrm{~m}^{2} \cdot \mathrm{h}^{-1}\right]}\end{array}$ & $\begin{array}{l}\text { Excess of Natural } \\
\text { Ventilation }\left[\mathrm{h}^{-1}\right]\end{array}$ \\
\hline \multirow{3}{*}{ n.1 } & none & 2513 & 14.1 & 0.71 & 42.3 & 11.1 & 0.41 \\
\hline & $\begin{array}{l}\text { rubber } \\
\text { seals }\end{array}$ & 1889 & 10.6 & 0.53 & 31.8 & 8.3 & 0.23 \\
\hline & substitution & 4918 & 27.6 & 1.38 & 82.8 & 21.7 & 0.88 \\
\hline \multirow{2}{*}{ n. 2} & none & 5968 & 13.7 & 0.68 & 49.3 & 14.3 & 0.38 \\
\hline & substitution & 5126 & 13.0 & 0.65 & 42.3 & 12.8 & 0.35 \\
\hline \multirow{2}{*}{ n. 3} & none & 1005 & 7.3 & 0.37 & 20.2 & 7.4 & 0.07 \\
\hline & substitution & 629 & 4.6 & 0.23 & 12.6 & 4.6 & -0.07 \\
\hline
\end{tabular}

Table 3. Energy demand due to air leakages (without Mechanical controlled ventilation, VMC).

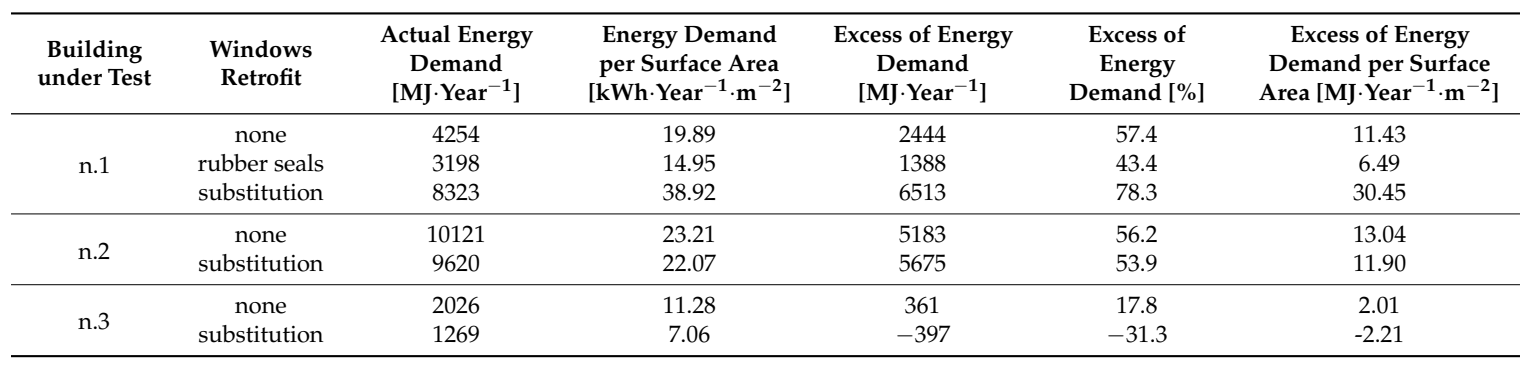

From the analysis of data in Tables 2 and 3 it can be pointed out that:

- $\quad$ in building 1 , in the case of new rubber seals on the window frames, the air change rate $n_{50}$ decreases by $24.8 \%$ compared to simple wooden windows. Unexpectedly, in the case of complete substitution of windows with new certified PVC windows, $n_{50}$ increases by $95.6 \%$ compared to the previous simple wooden windows with unacceptable air leakages;

- $\quad$ in building 2, the new certified aluminum windows exhibit a better air change rate $n_{50}$ improved by $4.9 \%$ compared to the simple wooden windows;

- in building 3, the new sealed aluminum windows exhibit an air change rate $n_{50}$ reduced by $37.4 \%$ compared to the previous simple wooden windows. According to data in Table 3, this occurrence resulted in a reduction of the energy demand but it could lead to unforeseeable effects on the indoor air quality (in the absence of a ventilation system).

It can be pointed out that the retrofit with rubber seals first adopted in building 1 resulted in a relevant improvement of window air-tightness. This is probably due to the previous ineffective seal guaranteed by the existing wooden windows, which in some cases presented visible interspaces between the window and the frame.

On the other hand, results on buildings 2 and 3 have to be further analyzed. In fact, a relevant worsening of air-tightness after the complete substitution of windows was observed in building 1 . Thus, the authors carefully investigated possible air leakages through windows by means of a hot wire anemometer and found at least two windows incorrectly installed (the presence of specific leakages was detected). This was demonstrated also for building 2 where the minor improvement of window air-tightness ( $n_{50}$ decreases only from 13.7 to $13.0 \mathrm{~h}^{-1}$ ) can be ascribed to the fact that one leaky window was found. Therefore, window retrofits sometimes lead to a worsening of the air-tightness performance despite the use of air-tight-certified windows, due to evident installation issues. 
In Figure 1, a comparison between the experimental results of $n_{50}$ and the corresponding values defined by EN 15242 [34] is depicted. In order to accurately evaluate the energetic efficiency of the investigated window retrofits, the energy consumptions of the ventilation system have been estimated according to EN ISO 13790 Standard [35].
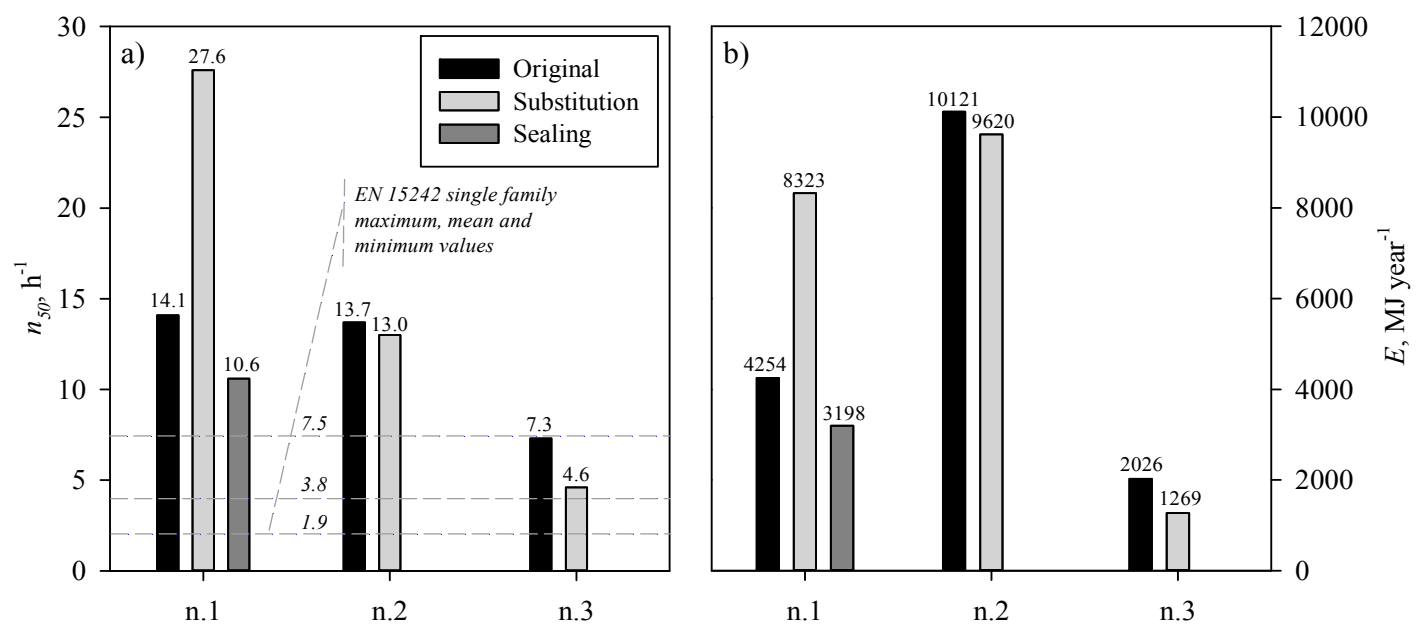

Figure 1. Comparison between: (a) experimental $n_{50}$ and corresponding values of EN 15242 Standard; (b) actual energy demand for the three buildings.

It is important to highlight that measured air permeability values result in a meaningful variation of the energy performance that is often disregarded also by skilled technicians who focus their interest mainly on the thermal transmittance of the window (Figure 1b). In particular, the energy demand owing to the ventilation is proportional to the building air permeability (in the absence of mechanical ventilation). Moreover, the increase of the Energy Performance Index per area leads to a shift of the building energy class, especially in colder areas and in the presence of high heated volumes.

\section{Conclusions}

This research was aimed at assessing the effectiveness of window retrofits in terms of air-tightness and building energy demand. To this aim, the authors designed and developed a specific air-tightness measurement campaign carried out by means of the BDT test technique in three buildings (located in the same Mediterranean climatic area) in which different window retrofits were adopted (new rubber seals on the window frames and substitution with low-thermal-transmittance air-tight windows).

The authors demonstrated that the substitution of windows could result in an increase of air leakages and the related energy demand in case of a not-fully-effective installation. This occurrence, which is due to the installer care and it is very hard to control, dramatically reduces the effectiveness in terms of the air-tightness of substitute window, which is often the only applicable building retrofit when aesthetic or historical constraints exclude intervention on the façade. On the other hand, air-tight windows can lead to relevant energy savings but, unfortunately, also to a strong reduction of the natural ventilation with consequent IEQ worsening and/or possible surface condensation phenomena. This is particularly relevant when the application of rubber seals on the window frames is adopted as the first cheap and non-invasive retrofit.

These results provide useful evidence to start a discussion focused on the characterization and the assessment of air leakages of windows. In particular, it will be useful in investigating how installation can affect air leakages by testing buildings with windows of the same air-tight class according to EN 12207 and the corresponding IEQ conditions.

From this perspective, EPBD Standards should take into account window air leakages when the building energy demand is calculated. This is a crucial issue, because a significant part of the existing building stock has to be reconverted to Nearly Zero Energy Building (NZEB). To this aim, specific 
BDT investigations should be carried out before and after retrofitting. In fact, the costs of BDTs are negligible if compared to the entire retrofit costs and to the achievable energy savings.

Acknowledgments: A significant part of this research was developed within the project SMART-CASE Soluzioni innovative multifunzionali per l'ottimizzazione dei consumi di energia primaria e della vivibilità indoor nel sistema edilizio PON 2007-2013 Ricerca e Competitività financed by The Italian Ministry of Education, Universities and Research.

Author Contributions: All authors contributed in equal amounts to the whole research activity here discussed. In particular, Francesca Romana d'Ambrosio Alfano and Marco Dell'Isola designed this research; the experimental measurement campaign was designed and performed by Marco Dell'Isola and Giorgio Ficco; the results' analysis was performed by Boris Igor Palella and Giuseppe Riccio; English editing was done by Giorgio Ficco and Boris Igor Palella. All authors have read and approved the final manuscript.

Conflicts of Interest: The authors declare no conflict of interest.

\section{Acronyms and Symbols}

$\begin{array}{ll}\Delta p & \text { Indoor-Outdoor Static Pressure Difference, Pa } \\ A_{E} & \text { Envelope area, } \mathrm{m}^{2} \\ A_{F} & \text { Net flow area, } \mathrm{m}^{2} \\ \mathrm{ACH} & \text { Air Changes per Hour, } \mathrm{h}^{-1} \\ \mathrm{BDT} & \text { Blower Door Test } \\ C_{\text {env }} & \text { flow coefficient, } \mathrm{m}^{3} \mathrm{~h}^{-1} \\ \mathrm{DD} & \text { degree-day, }{ }^{\circ} \mathrm{C} \\ \mathrm{EPBD} & \text { Energy Performance of Buildings } \\ \mathrm{HVAC} & \text { Heating Ventilation and Air Conditioning } \\ \mathrm{IAQ} & \text { Indoor Air Quality } \\ \mathrm{IEQ} & \text { Indoor Environmental Quality } \\ n & \text { Air Pressure Exponent, } 1 \\ n_{n a t} & \text { Natural air flow rate, } \mathrm{h}^{-1} \\ n_{50} & \text { Air change rate, } \mathrm{h}^{-1} \\ N & \text { Nearly Zero Energy Buildings } \\ q_{a 50} & \text { Air permeability, } \mathrm{m} \cdot \mathrm{h}^{-1} \\ q_{50} & \text { Air flow rate at } \Delta p=50 \text { Pa, } \mathrm{m}^{3} \cdot \mathrm{h}^{-1} \\ q_{e n v} & \text { Air flow rate through the building envelope, } \mathrm{m}^{3} \cdot \mathrm{h}^{-1} \\ V & \text { Internal Volume, } \mathrm{m}^{3} \\ \mathrm{VMC} & \text { Mechanical controlled ventilation } \\ w_{50} & \text { Specific leakage rate, } \mathrm{m} \cdot \mathrm{h}^{-1} \\ & \end{array}$

\section{References}

1. Guedi Capeluto, I.; Ochoa, C.E. Simulation-based method to determine climatic energy strategies of an adaptable building retrofit façade system. Energy 2014, 76, 375-384. [CrossRef]

2. Massimo, A.; Dell'Isola, M.; Frattolillo, A.; Ficco, G. Development of a geographical information system (GIS) for the integration of solar energy in the energy planning of a wide area. Sustainability 2014, 6, 5730-5744. [CrossRef]

3. Ficco, G.; Iannetta, F.; Ianniello, E.; d'Ambrosio Alfano, F.R.; Dell'Isola, M. U-value in situ measurement for energy diagnosis of existing buildings. Energy Build. 2015, 104, 108-121. [CrossRef]

4. Celenza, L.; Dell'Isola, M.; Ficco, G.; Palella, B.I.; Riccio, G. Heat accounting in historical buildings. Energy Build. 2015, 97, 47-56. [CrossRef]

5. Asdrubali, F.; Baldinelli, G.; Bianchi, F. Influence of cavities geometric and emissivity properties on the overall thermal performance of aluminum frames for windows. Energy Build. 2013, 60, 298-309. [CrossRef]

6. Baldinelli, G.; Asdrubali, F.; Baldassarri, C.; Bianchi, F.; D’Alessandro, F.; Schiavoni, S.; Basilicata, C. Energy and environmental performance optimization of a wooden window: A holistic approach. Energy Build. 2014, 79, 114-131. [CrossRef] 
7. Van Den Bossche, N.; Huyghe, W.; Moens, J.; Janssens, A.; Depaepe, M. Air-tightness of the window-wall interface in cavity brick walls. Energy Build. 2012, 45, 32-42. [CrossRef]

8. Parliament of the European Union. The Energy Performance of Building (Recast). Directive 2010/31/EU, 19 May 2010.

9. The European Portal for Energy Efficiency in Buildings. Available online: http:/ /www.buildup.eu/sites / default/files/content/Overview\%20article\%20Airtightness\%2019032013.pdf (accessed on 31 August 2016).

10. Buildings Performance Institute Europe (BPIE). Indoor Air Quality, Thermal Comfort, and Daylight: Analysis of Residential Building Regulations in Eight EU Member States; BPIE: Brussels, Belgium, 2015.

11. European Committee for Standardization (CEN). Thermal Performance of Buildings e Determination of Air Permeability of Buildings e Fan Pressurization Method; EN Standard 13829; European Committee for Standardization: Brussels, Belgium, 2000.

12. International Organization for Standardization (ISO). Thermal Performance of Buildings-Determination of Air Permeability of Buildings_Fan Pressurization Method; ISO Standard 9972; International Organization for Standardization: Geneva, Switzerland, 2006.

13. Air Infiltration and Ventilation Centre (AIVC). Building Air-Tightness: A Critical Review of Testing, Reporting and Quality Schemes in 10 Countries; TightVent Report n. 4 (AIVC Document AIC-TN67); AIVC: Paris, France, 2012.

14. American Society of Heating, Refrigerating and Air-Conditioning Engineers (ASHRAE). Infiltration and Ventilation Requirements. In ASHRAE Handbook of Fundamentals; American Society of Heating, Refrigerating and Air Conditioning Engineers: Atlanta, GA, USA, 2009; Chapter 27.

15. Emmerich, S.J.; Persily, A.K.; McDowell, T.P. Impact of Infiltration on Heating and Cooling Loads in U.S. Office Buildings; Building and Fire Research Laboratory, National Institute of Standards and Technology Gaithersburg: Madison, WI, USA, 2007.

16. Chan, W.R.; Nazaroff, W.W.; Price, P.N.; Sohan, M.D.; Gadgil, A.J. Analyzing a database of residential air leakage in United States. Atmos. Environ. 2005, 39, 3445-3455. [CrossRef]

17. Kalamees, T. Air-tightness and air leakages of new lightweight single-family detached houses in Estonia. Build. Environ. 2007, 42, 2369-2377. [CrossRef]

18. Sherman, M.H.; Dickerhoff, D.J. Air-tightness of USA dwellings. ASHRAE Trans. 1998, 104, $1359-1367$.

19. Sfakianaki, A.; Pavlou, K.; Santamouris, M.; Livada, I.; Assimakopoulos, M.; Mantas, P.; Christakopoulos, A. Air-tightness measurements of residential houses in Athens, Greece. Build. Environ. 2008, 43, 398-405. [CrossRef]

20. D'Ambrosio Alfano, F.R.; Dell'Isola, M.; Ficco, G.; Tassini, F. Experimental analysis of air-tightness in Mediterranean buildings using the fan pressurization method. Build. Environ. 2012, 53, 16-25. [CrossRef]

21. D'Ambrosio Alfano, F.R.; Ficco, G.; Palella, B.I.; Riccio, G.; Ranesi, A. An Experimental Investigation on the Air Permeability of Passive Ventilation Grilles. Energy Procedia 2015, 78, 2869-2874. [CrossRef]

22. D'Ambrosio Alfano, F.R.; Olesen, B.W.; Palella, B.I.; Riccio, G. Thermal comfort: Design and assessment for energy saving. Energy Build. 2014, 81, 326-336.

23. Buonanno, G.; Morawska, L.; Stabile, L. Particle emission factor during cooking activities. Atmos. Environ. 2009, 43, 3235-3242. [CrossRef]

24. Alcamo, J.; Olesen, J.E. Climate and climate change. In Life in Europe under Climate Change; Wiley Blackwell: Chichester, UK, 2012; Chapter 2.

25. American Society of Heating, Refrigerating and Air Conditioning Engineers (ASTM). Ventilation and Acceptable Indoor Air Quality in Low-Rise Residential Buildings Infiltration and Ventilation Requirements; ANSI/ASHRAE Standard 62.2-2016; American Society of Heating, Refrigerating and Air Conditioning Engineers: Atlanta, GA, USA, 2016.

26. European Committee for Standardization (CEN). Windows and Doors-Air Permeability-Classification; EN Standard 12207; European Committee for Standardization: Brussels, Belgium, 1999.

27. Repubblica Italiana. Regolamento Recante Norme per la Progettazione, l'Installazione, l'Esercizio e la Manutenzione Degli Impianti Termici Degli Edifici ai Fini del Contenimento dei Consumi di Energia, in Attuazione Dell'Art. 4, Comma 4, Della Legge 9 Gennaio 1991, n. 10. DPR 412/1993. GU n.242, del 14.10.1993, S.O.8; Available online: http://www.gazzettaufficiale.it/eli/id/1993/10/14/093G0451/sg (accessed on 26 September 2016). 
28. European Committee for Standardization (CEN). Windows and Doors-Air Permeability-Test Method; EN Standard 1026; European Committee for Standardization: Brussels, Belgium, 2000.

29. American Society for Testing and Materials (ASTM). Standard Test Method for Determining Air Leakage Rate by Fan Pressurization; ASTM Standard E779; American Society of Testing and Materials: Philadelphia, PA, USA, 2010.

30. Sherman, M.H.; Chan, W.R. Building Air-Tightness: Research and Practice; Lawrence Berkeley National Laboratory Report No. LBNL-53356; Lawrence Berkeley National Laboratory: Berkeley, CA, USA, 2004.

31. Sherman, M.H. Estimation of infiltration from leakage and climate indicators. Energy Build. 1987, 10, 81-86. [CrossRef]

32. Dubrul, C. Inhabitants Behaviour with Respect to Ventilation; Technical Note 23; AIVC: Coventry, UK, 1988.

33. American Society for Testing and Materials (ASTM). Standard Test Method for Airflow Calibration of Fan Pressurization Devices; ASTM Standard E1258; American Society for Testing and Materials: Philadelphia, PA, USA, 2008.

34. European Committee for Standardization (CEN). Ventilation for Buildings-Calculation Methods for the Determination of Air Flow Rates in Buildings Including Infiltration; EN Standard 15242; European Committee for Standardization: Brussels, Belgium, 2007.

35. European Committee for Standardization (CEN). Energy Performance of Buildings_Calculation of Energy Use for Space Heating and Cooling; EN Standard 13790; European Committee for Standardization: Brussels, Belgium, 2008.

(C) 2016 by the authors; licensee MDPI, Basel, Switzerland. This article is an open access article distributed under the terms and conditions of the Creative Commons Attribution (CC-BY) license (http:/ / creativecommons.org/licenses/by/4.0/). 